\title{
Transforming Engineering Education in India in terms of quality standards
}

\author{
Sreepavani. ${ }^{1}$, Jyothi Kalyan², Lakshmi Prasanna. $V^{3}$ \\ ${ }^{1}$ MBA, MLR Institute of Technology, Dundigal, Hyderabad \\ ${ }^{2}$ MBA, MLR Institute of Technology, Dundigal, Hyderabad \\ ${ }^{3}$ MBA, MLR Institute of Technology, Dundigal, Hyderabad \\ ${ }^{1}$ sri.pavani15@gmail.com \\ ${ }^{2}$ kalyanreddy.jyothi@gmail.com \\ ${ }^{3}$ vlprasanna527@gmail.com
}

\begin{abstract}
Engineering education in India is transforming over a period of time. The traditional teaching methods are being replaced by new teaching methods. Though many teaching learning practices are being adopted by the institutions the quality of the education is still limping. Government bodies like UGC and AICTE are evaluating the higher education system standards continuously but still the crisis in Indian engineering education is evident. Government reports shows that lakhs of engineering students are being graduated every year. Studies conducted so far on the engineering institutions concluded that though India is producing more number of engineering graduates the employability skills they acquire during their education period is very less, except those from prestigious institutions. Reasons may be different but the total effect is employability skills of graduates are diminishing. This paper discusses about strategies and pedagogies being implemented by the engineering colleges and challenges faced by Indian engineering education system and how to overcome these challenges.
\end{abstract}

Keywords: Higher education, Engineering, Teaching, Learning, Quality, Pedagogies

\section{Introduction}

"India is a developing country" from decades back since our independence we are saying this. The question is even after more than 70 years of independence why we are still saying India is a developing country? The reason is we are growing in number (population multiplication) but the basic needs are not being fulfilled to all the citizens.

\footnotetext{
Corresponding author

Sreepavani.V

MBA, MLR Institute of Technology, Dundigal,Hyderabad sri.pavani15@gmail.com
}

According to Indian constitution 'right to education' is one of the basic rights of its citizens. Indian education consists of three stages: Primary, Upper Primary (middle) and higher education (professional).Engineering is one of the higher education program been offered to the students who are living in every corner of the country with an aim to enhance the learning capabilities of students in the area of science and technology, agriculture and bio-sciences with a view of making them more employable in the area of their study.

While recent analysis on engineering education made it clear that the colleges are implementing traditional teaching pedagogy methods which are not sufficient to make the students employable and hence there is need to make changes in the current teaching and learning practices to transfer engineering education in the direction of making the students more employable than merely learning. The main strategy that can be implemented to prepare the students to face the challenges, is by helping them to build knowledge and skills in an easy way so that they can readily adapt them and address the novel, complex problems which they are going to encounter ${ }^{[5]}$.

India stands in first place with highest number of young population. Prime Minister Narendra Modi is hoping to reap this advantage by promoting 'Make in India' mission. But quality of current engineering education is playing a spoilsport ${ }^{[7]}$. Except some of the premier engineering colleges like IITs, IIITs, NITs and few private institutes most of the colleges providing engineering education are not able to provide the skills required to fetch the jobs to the students.

Study conducted by Indian Express explores that Russian and Chinese engineering students were performing better when compared to Indian students. This study shows the fact that Indian engineering students are not able to think creatively and innovatively. The reason behind this situation is lack of quality education which is halting the 
growth of students academically and professionally ${ }^{[7]}$. In order to find solution for this situation this paper tries to explore the problems in Indian engineering education system and suggests some strategies to overcome those.

\section{Review of literature}

Sujatha (2017) says that only $4.7 \%$ of the engineering students are capable of writing correct programming codes and is fit for IT industry on the other hand $60 \%$ of the students are not at all able to write any code. The reason for this is, in spite of charging huge amounts as fees from the students engineering colleges are failing to provide quality education in terms of practical ${ }^{[4]}$.

Jinu Kurian (2014) opines that Indian students are still studying the technology that is updated when India got independence, while other countries are moving forward with rocket speed. Jinu also states that there is huge gap between industry and institute and in order to fill this gap organisations should tie-up with institutions and provide summer internships ${ }^{[1]}$.

Samarth Bansal (2017) says that Indians are more fascinated for engineering education as they believe that person with engineering degree is more talented and is capable of doing the work better than others and also perceive that engineering students earn more when compared to Arts and Commerce ${ }^{[2]}$.

\section{Performance of Indian Engineering Education}

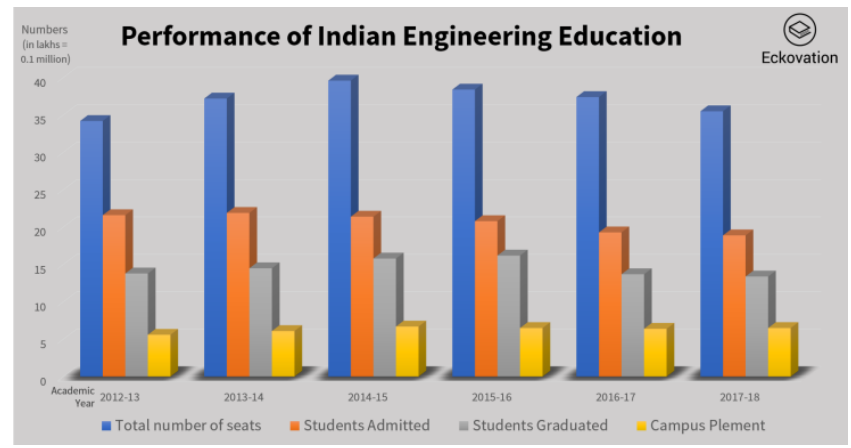

Source AICTE

From bar chart (AY 2012-13 to 2017-18) it is identified that from past 6 years only $50-60 \%$ of the seats are only getting filled. The infrastructure which is used to for building engineers is not being utilized properly ${ }^{[10]}$. Placements are even less than $30 \%$.

\section{Gaps in Engineering Education}

Studies so far conducted on engineering education system in India had concentrated in assessing on how good enough is a student to get employable after completion of his engineering education. That is they concentrated only on assessing the knowledge. The transformation is required in orientation of education. By definition engineering "the branch of science and technology concerned with the design, building, and use of engines, machines, and structures" i.e., engineering is a course that aims at getting the students employed along with inculcating the zeal to create and innovate products to meet the societal needs.

The gaps identified in Indian education system are:

1. Gap in Supply and Demand: Enrolment of engineering students in India is less (18\%) when compared to other countries in the world (China $26 \%$ and Brazil 36\%). But demand for engineering graduates in the organisations to work is very high.

2. Low quality in teaching and learning: Most of the colleges are not maintaining the required faculty student ratio proposed by AICTE. Even faculty development programs are not being conducted in many institutions which is making the faculty to lag with updated technology. The curriculum followed is also out-dated and what the students are learning in the classrooms is not useful practically outside.

3. Scanty focus on research: As many institutions are not hiring PhDs focus on research is very less. Even the facilities provided in India for research and development is also negligible. This is because of lack of innovation and less industry interaction.

4. Uneven distribution of resources: India remains highly divided with large population with high density in some areas. Access to engineering colleges is unevenly distributed, where more number of engineering colleges is distributed in South, producing more supply than demand. The case is opposite in eastern areas where supply is much lower than demand ${ }^{[9]}$.

This paper tries to suggest measures to be implemented to fill the above gaps; which are to be adapted by the government and the institutions to change the orientation from getting employment to generating employment.

\section{Discussions}

Many research reports sponsored by industry confirm that, there exists a huge gap between the industry expectations from engineering graduates and the actual skills possessed by them. The results of the study conducted by the National Association of Software and Service Companies (Nasscom) and McKinsey identified that there are huge number of openings in all the sectors but there will be a shortfall of $60 \%$ of students with qualified skills required to perform the job.

The worker deficit is not due to the lack of availability of graduates but lack of qualified workers. This situation has been raised because only one $25 \%$ of the engineering graduates and $10 \%$ graduates with general degrees are only meeting the requirements and expectations of multinational companies. This report also says that these graduates are lacking technical skills, English competency, communication and presentation skills and the ability to work as part of a team.

According to AICTE data, the number of students seeking admission into engineering courses has been witnessing a 
downfall i.e., about 75000 annually. The figure may go 80000 in the next year. Because of this reason around 200 colleges which are not having proper infrastructure has been voluntarily applying for closure.

The government of India has identified the problem of nonfilling of seats and poor quality of education long back and appointed a committee to evaluate the performance of technical institutions in the country. The committee was led by Dr.U.R.Rao scientist in ISRO. Findings of the committee are:

1. The number of engineering institutions has increased more than the growth of economy, especially private institutes.

2. Engineering colleges are not distributed equally on the basis of geography. This led to surplus in some areas and shortages in other.

3. Faculty student ratio is very less and most of the colleges do not contain doctorates and the system is not producing enough qualified doctorates.

4. Most of the colleges are not following the accreditation procedure.

5. There is no interaction between industry and classroom.

6. Increasing unemployment rate in engineering graduates.

7. Very high tuition fees in standard colleges.

8. Colleges are not able to produce skilled manpower to reach the needs of the industry. ${ }^{[8]}$

The committee has given the following suggestions:

1. The first step to control the situation is to ruthlessly close the institutions which do not have enough faculty members and infrastructure.

2. Faculty should get right pay for their work and more number of PhDs should be recruited.

3. Colleges should reduce the fees for merit poor students.

4. Government should play a vital role in regulating the institutions.

5. To bridge the vacuum of faculty, services of retired people must be used.

6. Centralized research facilities should be provided by the AICTE in centralized places $^{[3]}$.

The suggestions given by U.R.Rao were never followed as the government has changed in the next year. So the education system in India has also not changed and still in 2018 also we are studying about the same problems. Prof. Krishna Vedula has identified the following problems in Indian engineering education.

\section{Challenges of current Engineering Education in India}

The curriculum followed in many streams such as in the case of software engineering is often outdated Not only are our software professionals taught outdated programming languages, our engineers are asked to study old engineering and production techniques.

1. Mismatch between aspirations of engineering graduates and their employability.

2. Theoretical university syllabus with no link to upgrading industry applications.

3. Weak connection between industry and academia.

4. Exam centred traditional teaching methods.

It is also observed that in one of the curriculum designed by the university course,theory is being taught in one semester and application part (practicals) are being conducted in the other semester by the time which the student remember less basic of the course taught and in some cases it is almost the student has completely forgotten the course itself.

Parental Pressure: Survey conducted on 1000 engineering graduates at a conference in Hyderabad revealed that majority of the engineering graduates is pursuing the degree just because of the pressure from their parents ${ }^{[11]}$.

Students also confessed that they are continuously getting distraction from smartphones and are not able to cope up with the present social pressures.

This we can say from the increasing rate of suicides of engineering graduates even in prestigious institutions like IITS and other premium institutions..

\section{Initiations by Indian government to improve Engineering Education standards}

Thanks to our honourable Prime Minister Mr. Narendra Modi, with his initiation and focused educational reforms of Modi government, in 2014 India became permanent member of Washington Accord as the 16th member state. This makes the students graduating from Indian institutions accredited by National Accreditation Council to pursue their higher studies without appearing for the exam in other member countries institutions.

- For this government made National Board of Accreditation an independent organization from the regulatory body AICTE

- Launching of mission teacher and training

- Sub-mission on polytechnics under coordinated action for skill development

- Providing impetus to National Mission on Education through ICT etc.

Government has introduced choice-based credit system (CBCS) from the year 2016 in higher education. This gives open choice to students to select the subjects by their own and in their wished order. Some subjects are made compulsory which include basic and elective courses to have strong knowledge in their foundation courses and thus making the education more customized. The evaluation system was also changed from number to grade ${ }^{[6]}$.

As a part of Educational reforms innovations, Smart class and Edu India are considered as the best innovative methods for teaching students. In addition to this AICTE and University grant Commission (UGC) are encouraging the colleges to adopt Outcome-based education (OBE) 
system to improve the quality standards and student learning.

In addition to the above many online courses like National Programme on Technology Enhanced Learning (NPTEL) provides E-learning through online Web and Video courses in Engineering, Science and humanities streams. Here the courses are open for anyone to access - at no cost. So anyone who is interested in learning gets access to quality content, which also includes discussion with the content creator and access to assignments for self-testing. One more is Massive Open Online Course (MOOCS), it is a free, open, online course aimed at unlimited participation and is being offered to the students and faculty community. This helps in supporting active learning among the students ${ }^{[6]}$.

\section{Suggestions}

The first measure to Improve quality in engineering education is to lay foundations from elementary and secondary school education. Schools should change the curriculum so that students can learn engineering skills from an early stage. This should include offering classes that begin to develop engineering skills at an early point.

Four main measures to implement first are

1. Teaching and learning Innovations-Game based learning (Kahoot)

2. Outcomes Based Education

3. Industry Academy Partnerships - more than $20 \%$ of the syllabi in each course should be taught by the industry experts.

4. At least one certification course in the core area is to be offered to the students in association with industry partnership.

5. Entrepreneurship Education - rather than job orientation education train the students to create latest and innovative products and services with society based outlook.

Before it becomes too worse proper precautions have to be taken to form an eco-system by interlinking so many programs with others.

The Eco system should consists of

1. Certification - Every faculty and student should mandatorily complete any one certification course (NPTEL OR MOOCS).

2. Conferences - Conferences should we conducted in the institutions where students should perform important role in organising the events. In the same way students and faculty should attend conferences to learn the latest technologies used.

3. Courses -- Curriculum should be designed in such way that $20 \%$ of the syllabus should be thought by industry experts and practical periods should be more than theory periods. Labs and projects should start from second year itself. Subjects included in the course should not be same in all the regional areas. Courses should be offered basing on the employment opportunities near to that institute.
4. Governance \& Leadership - Public relations is the main skill to be developed by the students to work in the outside world. Students should be thought values and leadership skills along with their technical education.

5. Industry Partnership - Every institute should go for MoUs with all sectors of organisations. Organisations should also come up with excellence centres in the institutions. Institutions should appoint organization people as their board of studies member.

6. Journal - Student should be encouraged to publish articles in reputed journals.

7. Mentoring - Faculty should be assigned by a certain number of students, so that they can continuously mentor their progress. Even students can be appointed as mentors so that their leadership skills will be increased. Students should be encouraged for within group discussions.

8. Virtual Communications - Students should be provided with the opportunity to listen the lectures of International University professors and should develop contact with the international students.

9. Workshops - Workshops should be conducted to the students on latest technologies.

10. Training for Faculty - Proper training programs should be conducted for faculty on the changing technologies as they are the people who have to teach.

11. Engineering Institutions for Innovation Entrepreneurship - Engineering institutions with huge infrastructure can be used as a medium to promote entrepreneurship ${ }^{[12]}$.

\section{Conclusion}

In India the quality of the education and educational institutions is being rated based more on infrastructure and less on the standards of teaching and learning process. Firstly this has to be changed i.e in evaluating engineering educational Institutions equal weightage for infrastructure and teaching learning practices is to be given by the evaluating committees/ bodies while granting the approval for establishing the standard and substandard Engineering colleges. Secondly colleges and universities have to show keen interest in developing the curriculum especially syllabus contents because the current syllabi is outdate and is not being matched with industry requirements. Thirdly more of innovative TLP are to be implemented like Flipped classrooms, online student form for discussions etc. Fourthly Industry and academia interaction should be given importance in evaluation process.

\section{References}

1. Jinu Kurian (2014). Accessed on 16/12/2018 from https://www.quora.com/How-is-engineering- 
education-different-in-India-compared-toeducation-abroad

2. Samarth Bansal (2017). Accessed on 16/12/2018 from https://www.hindustantimes.com/indianews/is-the-engineering-dream-over-after-iitstudents-now-prefer-mba-and-govt-jobs/storyskQp6FdebWG7o1qSnnDUKO.html

3. Samir Kumar Saha and Sangita Ghosh (2012). Commissions \& Committees On Technical Education In Independent India: An Appraisal. Indian Journal Of History Of Science, 47.1 (2012) 109-138.

4. Sujatha (2017). Accessed on 16/12/2018 from https://www.mapsofindia.com/my-

india/society/engineer-education-in-india-fails-toimpart-requisite-skills

5. Thomas A. Litzinger, Lisa R. Lattuca, Roger G. Hadgraft, and Wendy C. Newstetter, Engineering Education and the Development of Expertise, Journal of Engineering Education January 2011, Vol. 100, No. 1, pp. 123-150.

6. http://www.geopolitika.hu/en/2017/05/09/educatio n-reform-in-india-the-power-of-knowledge-andinformation/

7. https://economictimes.indiatimes.com/articleshow/ $63680625 . \mathrm{cms}$ ?utm_source $=$ contentofinterest\&ut $\mathrm{m} \_$medium $=$text\&utm_campaign $=$cppst

8. https://wenr.wes.org/2007/01/wenr-january-2007engineering-education-in-india-a-story-ofcontrasts

9. https://www.britishcouncil.in/sites/default/files/un derstanding_india.pdf

10. https://engineering.eckovation.com/engineeringeducation-performance-report-engineeringcolleges-india/

11. https://www.thehindubusinessline.com/opinion/col umns/rajkamal-rao/engineering-education-needsserious-rethinking/article26297580.ece

12. https://www.indiatoday.in/educationtoday/featurephilia/story/6-ways-to-tackle-withcurrent-technical-education-system-problems1281082-2018-07-09. 